\title{
Mechanized surfacing of the end face of screw coils of a screw conveyor operating under abrasion conditions in a corrosive environment
}

\author{
Eugeniusz Turyk ${ }^{1, *}$, Svetlana Georgiyevna Grigorenko ${ }^{2}$, Igor Aleksandrovich Ryabtsev ${ }^{2}$ \\ ${ }^{1}$ Research Network ŁUKASIEWICZ - Welding Institute, Poland; \\ 2 E.O. Paton Electric Welding Institute of the National Academy of Sciences, Ukraine; \\ Svetlana Georgiyevna Grigorenko, Ph.D.; lanagrig@gmail.com \\ prof. Igor Aleksandrovich Ryabtsev; ryabtsev39@gmail.com \\ * Correspondence prof. Eugeniusz Turyk, eugeniusz.turyk@is.gliwice.pl
}

Received: 05.08.2019; Accepted: 02.11.2019

\begin{abstract}
The purpose of the work was to determine the possibility of the regenerative surfacing of the upper surface of screw conveyor coils. The screw conveyor, used for the transport of bulk materials in a corrosive environment, was originally surfaced with chromium cast iron. The research work discussed in the article resulted in the development of a MAG method-based technology enabling the repair surfacing of screw conveyor coils. The technology involved the use of an EnDOtec DO*11 flux-cored wire and required the previous removal of the hardened upper layer.
\end{abstract}

Keywords: MAG surfacing; screw conveyor; chromium cast iron

\section{Introduction}

The efficiency of the screw conveyor significantly depends on the degree of wear of the front (upper) surface of the screw coils transporting loose materials. In order to reduce the consumption of screws operated under abrasive wear conditions in the mining industry, the building materials industry, etc., the

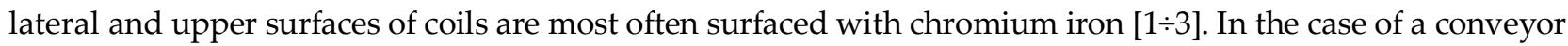
transporting dry minerals, EnDOtec DO 390 powder wire was used for the regenerative surfacing of the screw coils, providing a significant increase in wear resistance [4]. Unacceptable wear was also found in the case of the end face of screw coils operated in a corrosive environment.

Technological studies have shown the impossibility of surfacing of worn surfaces of the conveyor with the remainder of the hard layer due to the occurrence of unacceptable tears in the hard layer of chromium cast iron and in the buffer layer with a plasticity greater than the plasticity of the hard layer [4]. Therefore, the purpose of this work was to develop a regenerative surfacing technology for the upper surface of the $ø 478 \times 8 \mathrm{~mm}$ screw coils of a screw conveyor operated in conditions of metal-mineral wet abrasive wear, with the remainder of a hard layer of $5 \mathrm{~mm}$ thickness surfaced with chromium iron 500H27GS (Fe15 according to EN 14700) on lateral surface.

\section{Welding additional materials}

EnDOtec DO*11 powder wire was selected for surfacing, providing nickel-based weld metal,

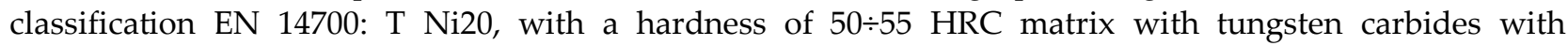
microhardness $\sim 2400 \mathrm{HV} 0.4[5,6]$. This wire is referred to as cermet wire, which makes it possible to make composite layers, padding weld layers composed of ceramic materials in a metal and alloy matrix [7:9]. The indicator of relative wear resistance of layers surfaced with EnDOtec DO*11 wire, determined in accordance with ASTM G 65 "Standard Test Method for Measuring Abrasion Using the Dry Sand/Rubber Wheel Apparatus", ranges from 3.22 to 5.67 compared to hardened steel resistant to abrasion, hardness 400 HB (index =1), depending on the technological conditions of surfacing for the amount of heat introduced from 0.29 to $0.96 \mathrm{~kJ} / \mathrm{mm}[10]$.

To make the buffer layer, EnDOtec DO*02 powder wire was used, classification EN 14700: T Fe10, EN ISO 17633-A: T 188 Mn MM2 [11], recommended by the EnDOtec DO*11 wire manufacturer. 
As a shielding gas, ISO 14175 - M12 - ArC - 2.5 gas mixture was used, recommended for surfacing of the abovementioned wires.

\section{Determining the maximum thickness of the working layer surfaced with the EnDOtec DO*11 wire}

In order to determine the permissible maximum thickness of the working layer, a buffer layer was surfaced on the end face of the coil with a working layer using the EnDOtec DO*11 wire, laying successive beads on top of each other.

Before surfacing the buffer layer, the hard layer was removed from the end face of the screw coil. To remove this layer, plasma cutting was used, cutting the base material $5 \mathrm{~mm}$ below the fusion line of the layer on this surface. The surface was then grinded by hand, leaving a hard layer on the lateral surface of the screw coils. The total thickness of the buffer and hard (working) layers needed to complete was $15 \mathrm{~mm}$.

The repeatability of the surfacing technological conditions was ensured using a mechanized process at the Multi Surfacer D2 Welding Alloys laboratory welding station, the surfacing was carried out using a standard arc, i.e. without controlling parameters and pulsating mode. The technological conditions selected during tests for mechanized surfacing of the buffer layer with EnDOtec DO * 02 wire with a diameter of $1.6 \mathrm{~mm}$ are given in table I.

Table I. Conditions of the buffer layer surfacing with EnDOtec DO*02 wire

\begin{tabular}{ccccccc}
\hline $\begin{array}{c}\text { Current } \\
\text { intensity, } \\
\text { A }\end{array}$ & $\begin{array}{c}\text { Wire feed rate, } \\
\text { m/min }\end{array}$ & $\begin{array}{c}\text { Arc voltage, } \\
\text { V }\end{array}$ & $\begin{array}{c}\text { Surfacing } \\
\text { speed, } \\
\text { cm/min }\end{array}$ & $\begin{array}{c}\text { Oscillation } \\
\text { Speed, } \\
\text { mm/min }\end{array}$ & $\begin{array}{c}\text { Oscillation } \\
\text { amplitude, } \\
\text { mm }\end{array}$ & $\begin{array}{c}\text { Oscillation } \\
\text { stop time, } \\
\text { s }\end{array}$ \\
\hline $205 \div 212$ & 4.5 & 21.0 & 22.4 & 1000 & 2 & 0.05 \\
\hline
\end{tabular}

The width of the padding weld made with EnDOtec DO*02 wire was $11.5 \div 12.2 \mathrm{~mm}$, and the thickness of the surfaced layer in one pass $-3.0 \mathrm{~mm}$. Visual tests showed the transition to a small depth of the buffer layer of cracks from the hard layer to the lateral surface of the screw coils, while no cracks were found from the side of the coil without a side hardening layer.

Then, the buffer layer, previously made on the end face of the coil, was surfaced with the working layer using EnDOtec $\mathrm{DO}^{*} 11$ wire. The surfacing parameters determined during tests ensuring the proper formation of the bead surfaced using the EnDOtec DO*11 wire on the buffer layer are given in table II. The amount of heat introduced was $0.7 \div 0.77 \mathrm{~kJ} / \mathrm{mm}$.

Table II. Conditions of the face surfacing with EnDOtec DO*11 wire

\begin{tabular}{ccccccc}
\hline $\begin{array}{c}\text { Current } \\
\text { intensity, } \\
\text { A }\end{array}$ & $\begin{array}{c}\text { Wire feed rate, } \\
\mathbf{m} / \mathbf{m i n}\end{array}$ & $\begin{array}{c}\text { Arc voltage, } \\
\mathbf{V}\end{array}$ & $\begin{array}{c}\text { Surfacing } \\
\text { speed, } \\
\mathbf{c m} / \mathbf{m i n}\end{array}$ & $\begin{array}{c}\text { Oscillation } \\
\text { Speed, } \\
\mathbf{m m} / \mathbf{m i n}\end{array}$ & $\begin{array}{c}\text { Oscillation } \\
\text { amplitude, } \\
\text { mm }\end{array}$ & $\begin{array}{c}\text { Oscillation } \\
\text { stop time, } \\
\text { s }\end{array}$ \\
\hline $146 \div 161$ & 3.4 & $22.0 \div 22.1$ & 22.1 & 1000 & 3 & 0.15 \\
\hline
\end{tabular}

The width of the padding weld was $11.5 \div 12.0 \mathrm{~mm}$, the thickness of the surfaced bead in one pass $-1.5 \mathrm{~mm}$. In subsequent beads, there were single transverse cracks, and during the cooling of the sixth bead, a detachment of the padding weld's section with a thickness of $8.5 \div 9.0 \mathrm{~mm}$ was observed (Fig. 1).

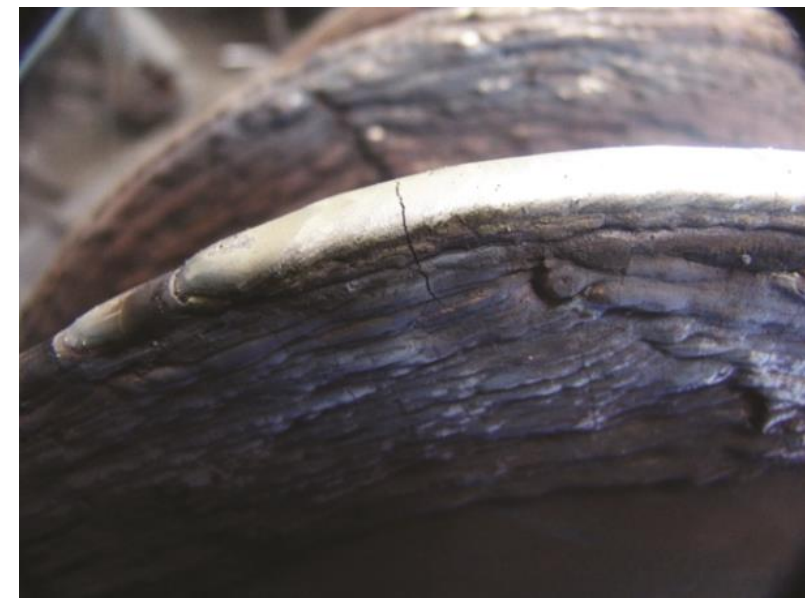

(a)

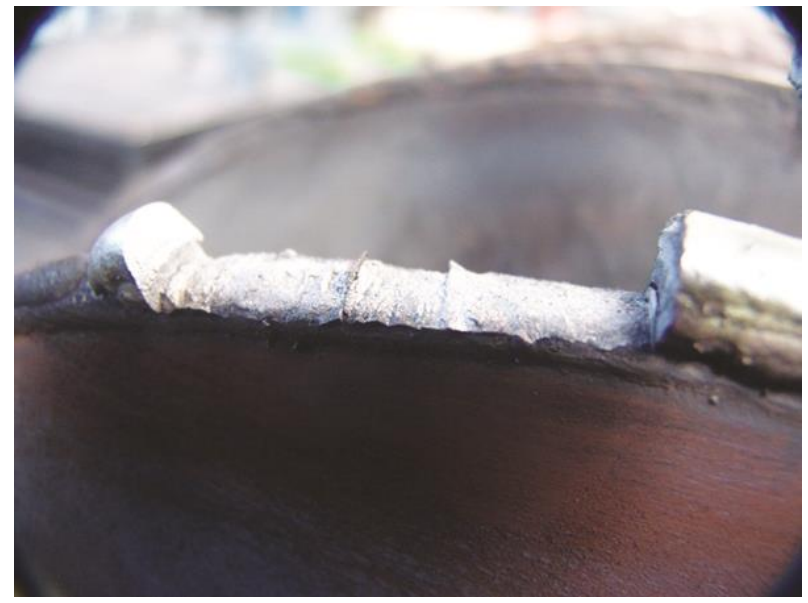

(b)

Fig. 1. Cracks (a) and detachment (b) of the sixth surfaced layer with wire EnDOtec DO*11 
This allows us to state that under test conditions it is possible to perform the multi-run surfacing process without tearing the working layer with a maximum thickness of $7 \mathrm{~mm}$, and the maximum number of beads laid using the EnDOtec DO*11 wire is 5.

\section{Simulation of surfacing process after removing the hard layer from the end face of the screw coil}

In order to check the variant of the conveyor's surface repair process after removing the hardening layer from the end face of the screw coil, determining the thickness of layers and hardness of the padding weld made with one, two, three and four layers, tests were carried out on surfacing of plates simulating the conveyor coils and testing of surfaced layers. The tests were carried out on flat plates of S355JR grade steel 8x250x120 mm. The side layer, buffer layer and upper working layer (beads $1 \div 4$ ) were surfaced on the plates according to figure 2 .

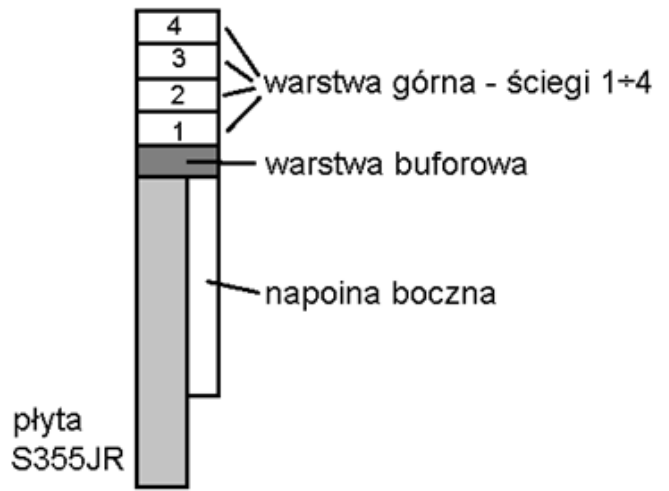

Fig. 2. Layer arrangement during the simulation of the conveyor screw repair after removal of the hard layer from the front face of the screw coil

The lateral surface was surfaced with self-shielding powder wire providing a 500H27GS chromium iron alloy (Fe15 according to EN 14700), similar to the regeneration screw. 12 beads were laid over the width of the $40 \mathrm{~mm}$ side surface, the thickness of the surfaced layer was $4.5 \div 5.0 \mathrm{~mm}$. In the surfaced layer, cracks $\leq 0.3 \mathrm{~mm}$ wide were found.

The technological conditions selected during tests for mechanized surfacing in the flat position of the buffer and working layer are summarized in tables III and IV.

Table III. Conditions of the buffer layer surfacing with EnDOtec DO*02 wire during the simulation of the conveyor screw repair

\begin{tabular}{ccccccc}
\hline $\begin{array}{c}\text { Current } \\
\text { intensity, } \\
\text { A }\end{array}$ & $\begin{array}{c}\text { Wire feed rate, } \\
\mathbf{m} / \mathbf{m i n}\end{array}$ & $\begin{array}{c}\text { Arc } \\
\text { voltage, } \\
\mathbf{V}\end{array}$ & $\begin{array}{c}\text { Surfacing } \\
\text { speed, } \\
\mathbf{c m} / \mathbf{m i n}\end{array}$ & $\begin{array}{c}\text { Oscillation } \\
\text { Speed, } \\
\mathbf{m m} / \mathbf{m i n}\end{array}$ & $\begin{array}{c}\text { Oscillation } \\
\text { amplitude, } \\
\mathbf{m m}\end{array}$ & $\begin{array}{c}\text { Oscillation } \\
\text { stop time, } \\
\text { s }\end{array}$ \\
\hline $197 \div 208$ & 4.5 & $20.8 \div 21.0$ & 25.0 & 1500 & 3.0 & 0.35 \\
\hline
\end{tabular}

Table IV. Conditions of the face surfacing with EnDOtec DO*11 wire during the simulation of the conveyor screw repair

\begin{tabular}{ccccccc}
\hline $\begin{array}{c}\text { Current } \\
\text { intensity, } \\
\mathbf{A}\end{array}$ & $\begin{array}{c}\text { Wire feed rate, } \\
\mathbf{m} / \mathbf{m i n}\end{array}$ & $\begin{array}{c}\text { Arc } \\
\text { voltage, } \\
\mathbf{V}\end{array}$ & $\begin{array}{c}\text { Surfacing } \\
\text { speed, } \\
\mathbf{c m} / \mathbf{m i n}\end{array}$ & $\begin{array}{c}\text { Oscillation } \\
\text { Speed, } \\
\mathbf{m m} / \mathbf{m i n}\end{array}$ & $\begin{array}{c}\text { Oscillation } \\
\text { amplitude, } \\
\mathbf{m m}\end{array}$ & $\begin{array}{c}\text { Oscillation } \\
\text { stop time, } \\
\text { s }\end{array}$ \\
\hline $140 \div 153$ & 3.4 & $21.9 \div 22.0$ & 22.0 & 1000 & 4.0 & 0.35 \\
\hline
\end{tabular}

The amount of heat introduced: $0.67 \div 0.73 \mathrm{~kJ} / \mathrm{mm}$.

Thickness of the layer surfaced using the EnDOtec DO*02 powder wire in one pass was $3.5 \mathrm{~mm}$. The width of the buffer layer was $13.0 \mathrm{~mm}$.

Thickness of the layer surfaced using the EnDOtec DO*11 powder wire in one pass was $1,5 \mathrm{~mm}$. The width of the padding weld was $12.0 \div 12.5 \mathrm{~mm}$, it was slightly smaller than the width of the buffer layer.

The macrostructure of layers surfaced on test plates with parameters according to tables III and IV is shown in figure 3. 


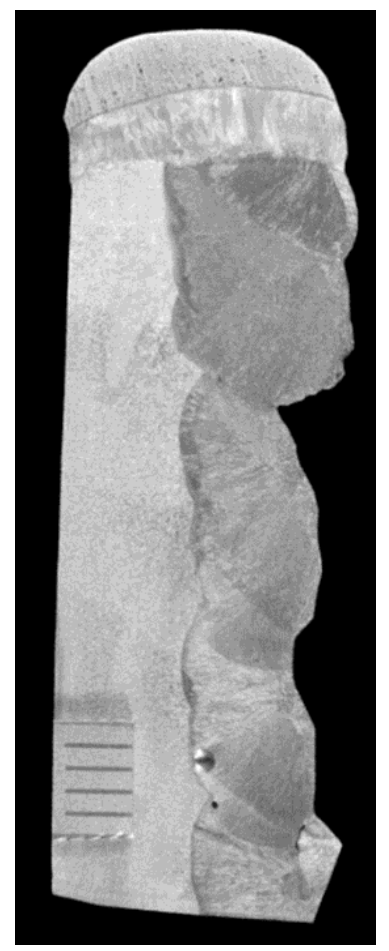

(a) plate no. 31

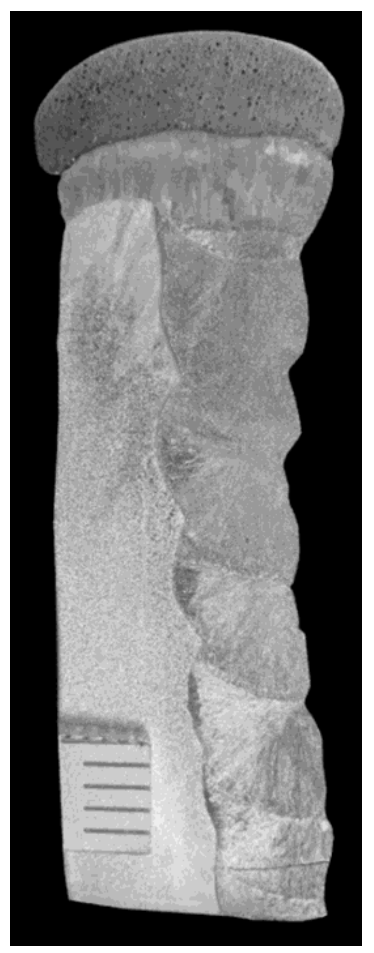

(b) plate no. 32

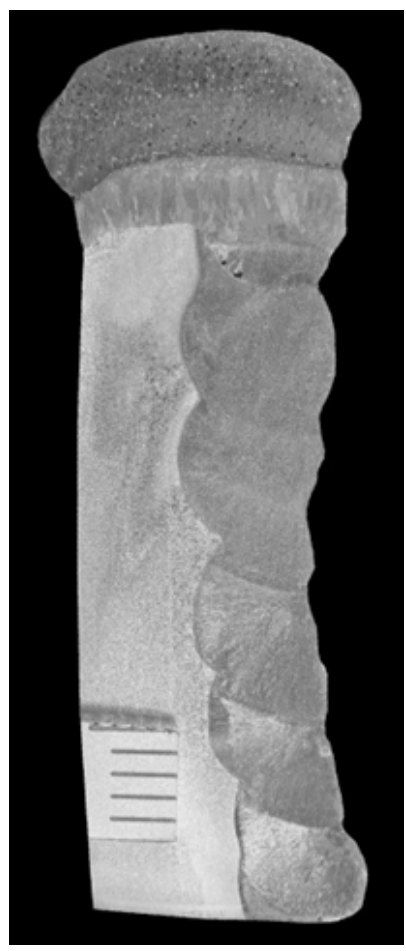

(c) plate no. 33

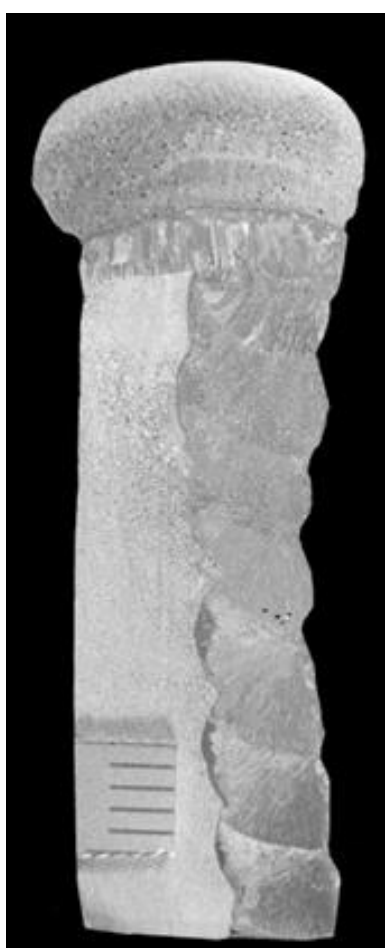

(d) plate no. 34

Fig. 3. Macrostructure of surfaced plates with the overlay weld on the face laid: a) in a single run - thickness 6 mm including the buffer layer, b) in two runs, c) in three runs, d) in four runs - thickness $10 \mathrm{~mm}$ including the buffer layer

The macroscopic tests did not show any unacceptable tears, but cracks $\leq 0.25 \mathrm{~mm}$ wide were found in the surfaced layers, acceptable by the user of the screw conveyor. In the padding welds there were also single gas bubbles, of a size not exceeding $2 \mathrm{~mm}$, i.e. permissible according to point 7.5.2 PN-EN ISO 156147:2016-12.

Then, microscopic metallographic tests were performed on the specimens. The microstructures were revealed in two stages using the Nital digesting reagent and electrolytic digestion, shown in figures 4 and 5 .

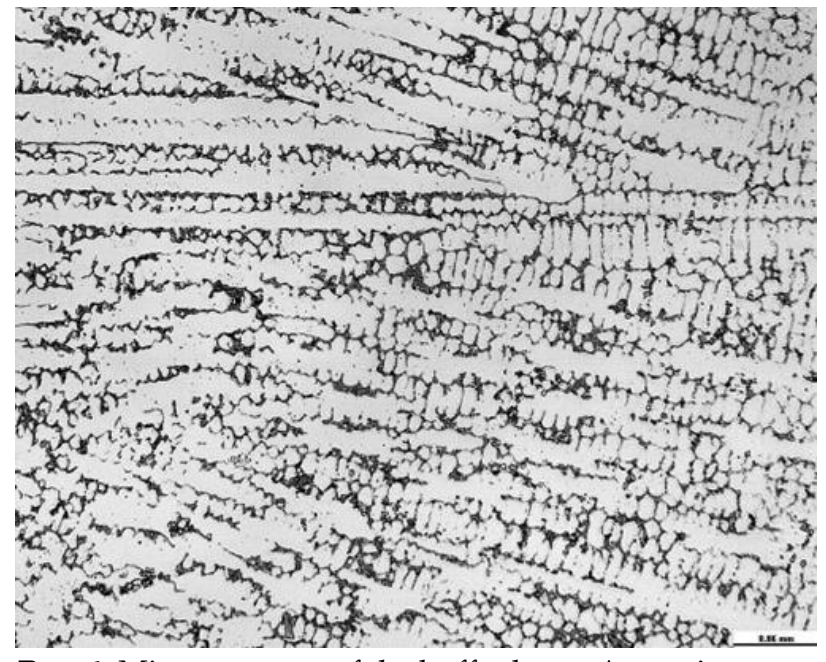

Rys. 4. Microstructure of the buffer layer. Austenite

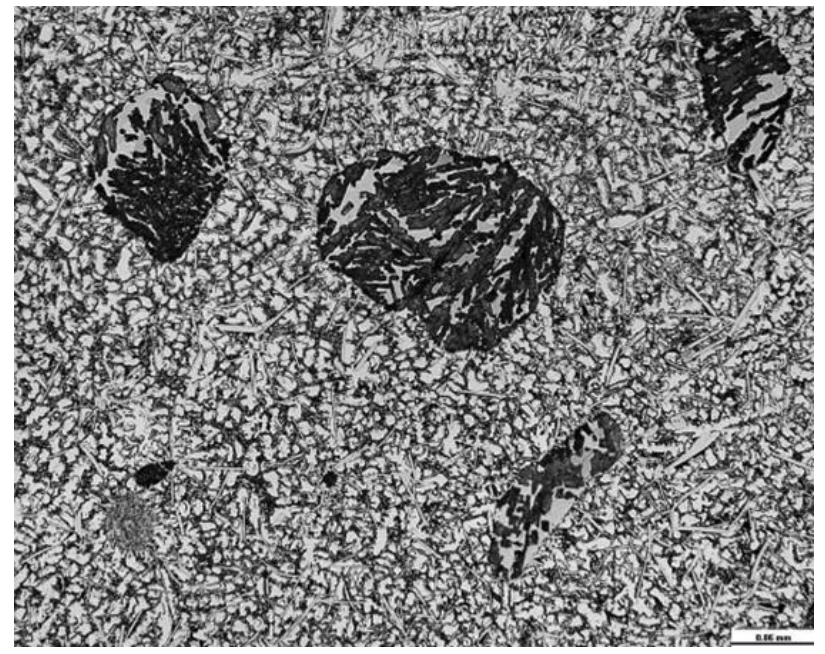

Fig. 5. Microstructure of the working layer. Carbides in a martensitic matrix

Hardness tests were also carried out in the surfaced layer, heat affected zone and base material. The distribution of measurement points is shown in figure 6 , and the results in table V. 


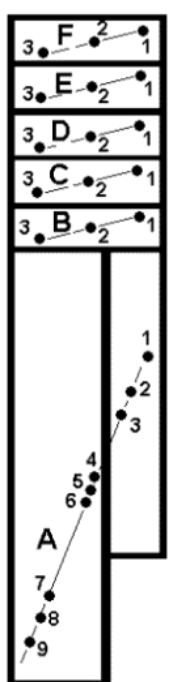

(a)

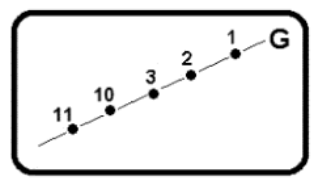

(b)

Fig. 6. Arrangement of hardness measurement points on the lateral surface (a) and on the grinded upper surface (b)

Table V. The results of hardness measurements of the surfaced test plates

\begin{tabular}{|c|c|c|c|c|c|c|c|c|c|c|c|c|}
\hline \multirow{3}{*}{$\begin{array}{c}\text { Sample } \\
\text { Plate } \\
\text { No. }\end{array}$} & \multirow{3}{*}{ Test line } & \multicolumn{11}{|c|}{ Measurement place according to figure 6 and HV10 hardness } \\
\hline & & \multicolumn{3}{|c|}{ Padding weld } & \multicolumn{3}{|c|}{ HAZ } & \multicolumn{3}{|c|}{ Basic material } & \multicolumn{2}{|c|}{ Padding weld } \\
\hline & & 1 & 2 & 3 & 4 & 5 & 6 & 7 & 8 & 9 & 10 & 11 \\
\hline \multirow{4}{*}{31} & A & 401 & 508 & 530 & 138 & 137 & 132 & 131 & 144 & 165 & - & - \\
\hline & B & 329 & 317 & 312 & - & - & - & - & - & - & - & - \\
\hline & $\mathrm{C}$ & 446 & 498 & 514 & - & - & - & - & - & - & - & - \\
\hline & G & 520 & 489 & 510 & - & - & - & - & - & - & 505 & 495 \\
\hline \multirow{7}{*}{34} & A & 455 & 459 & 433 & 155 & 138 & 136 & 133 & 133 & 132 & - & - \\
\hline & B & 333 & 325 & 312 & - & - & - & - & - & - & - & - \\
\hline & C & 413 & 380 & 421 & - & - & - & - & - & - & - & - \\
\hline & D & 473 & 548 & 503 & - & - & - & - & - & - & - & - \\
\hline & E & 548 & 548 & 579 & - & - & - & - & - & - & - & - \\
\hline & $\mathrm{F}$ & 483 & 450 & 525 & - & - & - & - & - & - & - & - \\
\hline & $\mathrm{G}$ & 520 & 499 & 515 & - & - & - & - & - & - & 490 & 520 \\
\hline
\end{tabular}

The hardness of the upper layer of the plate No. 31 surfaced with EnDOtec DO*11 powder wire in one pass (the first layer) was $489 \div 520 \mathrm{HV}(48.4 \div 50.5 \mathrm{HRC})$, and the plate No. 34 surfaced using multi-layer method (the fourth layer) was $450 \div 525 \mathrm{HV}(45.3 \div 50.8 \mathrm{HRC})$. The tests also showed that the HAZ hardness does not exceed $380 \mathrm{HV}$, meeting the requirements of PN-EN ISO 15614-7:2016-12, item 7.5.2, table IV.

\section{Surfacing of the upper surface of the screw coils after operation}

In the screw obtained for testing, the thickness of the upper layer was $10 \div 11 \mathrm{~mm}$. In order to regenerate the screw coils, the upper, surfaced layer was removed by plasma cutting from the non-surfaced side, $2 \div 3 \mathrm{~mm}$ below the fusion line of the upper layer, i.e. the height of the coil to be restored was $12 \div 13$ $\mathrm{mm}$, assuming $1 \mathrm{~mm}$ of machining allowance (grinding) of the restored upper surfaced layer.

The surface after plasma cutting was grinded in order to remove the slag residue and level the surface. Then, a buffer layer with EnDOtec DO*02 powder wire was made across the width of the base material of the coil and the side layer, so as to ensure separation of the side layer from the top layer laid next, preventing degreasing of this layer from the side layer. The buffer layer and then the upper layers on the end face of the coil were surfaced in a standard arc using the surfacing parameters given in the tables, respectively. During the tests it was found that surfacing with the use of powder wires can also be carried out using a pulsating arc using appropriate welding semiautomatic programs. The macrostructure of the surfaced coils is shown in figure 7. 


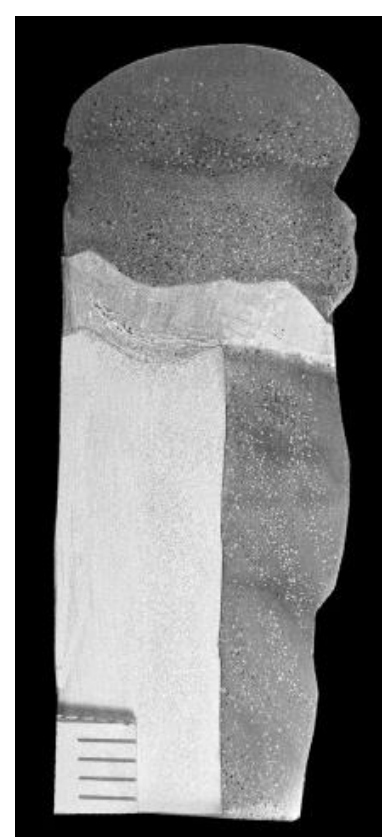

Fig. 7. Macrostructure of the screw coil with a $14 \mathrm{~mm}$ thick upper padding weld together with a buffer layer

\section{Conclusions}

On the basis of technological tests of MAG surfacing with powder electrode wire with metallic core EnDOtec DO*11 (process 138 according to PN-EN ISO 4063) and tests of surfaced elements, the following conclusions can be drawn:

1. In the case of surfacing of the working layer of screw coils with the EnDOtec DO* 11 powder wire, it is possible, under test conditions, to apply multi-run surfacing without tearing the working layer with a maximum thickness of $7 \mathrm{~mm}$.

2. Technological research of surfacing of plates simulating conveyor coils after operation, showed the possibility of making the upper layer of coils in single-, double-, three- and four-layers, using EnDOtec $\mathrm{DO}^{*} 11$ powder wires, on a buffer layer surfaced with EnDOtec DO*02 powder wire.

Author Contributions: conceptualization M.B. and J.S., methodology M.B. and J.S.; investigation M.B.; discussion M.B. and J.S., writing-original draft preparation M.B. and editing J.S.

Conflicts of Interest: The authors declare no conflict of interest.

\section{References}

[1] Orlik A.G., Orlik G.V., Kobernik N.V., Mikheev R.S., Arc deposition of abrasion wear-resisting coatings on the working surfaces of conveyor screws, Welding International, 2017, Vol. 31(12), 945-950. [CrossRef]

[2] Li T.Z., Li L., Lu H., Parent L., Tian H., Chung R.J., Li D.Y., Effect of trace Ni on the resistance of high-Cr cast iron to slurry erosion, Wear, 2019, Vol. 426-427, A, 605-611. https://doi.org/10.1016/j.wear.2019.01.033

[3] Chen L., Stahl J. E., Zhao W., Zhou J., Assessment on abrasiveness of high chromium cast iron material on the wear performance of PCBN cutting tools in dry machining, Journal of Materials Processing Technology, 2018, Vol. 255, 110-120. [CrossRef]

[4] Turyk E., Riabcew I.A., Melcer M., Rebuilding of coils of screw conveyors with chromium cast iron hard layer, Welding Technology Review, 2018, Vol. 90(9), 24-27. [CrossRef]

[5] Fülldrahtelektrode EnDOtec $^{\circledR}$ DO $^{*} 11$ für hoch abrasionsbeständige Auftragungen. www.castolin.com (1.05.2019)

[6] Klimpel A., Klimpel A.S., Rzeźnikiewicz A., Napawanie zrobotyzowane GMA drutem proszkowym cermetalowym Ni-WC, z ruchem wahadłowym uchwytu, Biuletyn Instytutu Spawalnictwa w Gliwicach, 2005, Vol. 49(5), 71-76.

[7] Klimpel A., Lisiecki A., Klimpel A.S., Rzeźnikiewicz A., Robotized GMA surfacing of cermetal deposits, Journal of Achievements in Materials and Manufacturing Engineering, 2006, Vol. 18(1-2), 395-398. [Hyperlink]

[8] Klimpel A., Lisiecki A., Klimpel A.S., Rzeźnikiewicz A., Abrasive wear resistance of robotized GMA surfaced cermetal deposits, Archives of Materials Science and Engineering, 2007, Vol. 28(9), 565-572. [yyperlink] 
[9] Klimpel A., Czupryński A., Rzeźnikiewicz A., Wpływ kierunku i kąta pochylenia palnika GMA na jakość i własności technologiczne napoin wykonanych drutem cermetalowym, Welding Technology Review, 2005, Vol. 77(4-5), 38-44.

[10] Klimpel A., Dobrzański L.A., Kik T., Rzeźnikiewicz A., Robotized GMA surfacing of cermetalic layers, Journal of Achievements in Materials and Manufacturing Engineering, 2006, Vol. 17(1-2), 361-364. [Hyperlink]

[11] Fülldrahtelektrode EnDOtec DO*02 für Mischverbindungen und Auftragungen. www.castolin.com (1.05.2019)

(C) 2019 by the authors. Submitted for possible open access publication under the terms and conditions of the Creative Commons Attribution (CC BY) license (http://creativecommons.org/licenses/by/4.0/). 